\title{
Kinetic Study of Electrocatalytic Oxidation of Carbohydrates on Cobalt Hydroxide Modified Glassy Carbon Electrode
}

\author{
Ghasem Karim-Nezhad, ${ }^{* a}$ Mohammad Hasanzadeh, ${ }^{a}$ Lotfali Saghatforoush, ${ }^{a}$ Nasrin Shadjou, ${ }^{a}$ \\ Sohrab Earshad ${ }^{b}$ and Balal Khalilzadeh ${ }^{c}$ \\ a Department of Chemistry, Payame Noor University, Khoy, Iran \\ ${ }^{b}$ Department of Chemistry, Payame Noor University, Marand, Iran \\ ${ }^{c}$ Department of Chemistry, Arak University, Arak, Iran
}

\begin{abstract}
Este estudo investigou a oxidação eletrocatalítica de frutose, sacarose, glucose, lactose, arabinose e maltose em nanopartículas de hidróxido de cobalto eletrodepositadas na superfície de eletrodo de carbono vítreo em soluções alcalinas. Voltametria cíclica (VC), cronoamperometria (CA) e também medidas de polarização de estado estacionário foram empregados. Nos estudos de VC, na presença de carboidrato, o aumento na corrente de pico da oxidação do hidróxido de cobalto é seguido pelo decréscimo na correspondente corrente catódica. Isto indica que os carboidratos foram oxidados pelo mediador redox, o qual foi imobilizado na superfície do eletrodo, via um mecanismo eletrocatalítico. Com o uso da equação de Laviron, os valores dos coeficientes de transferência de elétron, anódicos e catódicos, e a constante da razão de transferência de carga para as espécies redox imobilizadas foram determinadas como $0,71 \pm 0,03,0,33 \pm 0,03$ e $0,21 \pm 0,02 \mathrm{~s}^{-1}$, respectivamente. A constante de velocidade, o coeficiente da transferência de elétron e os coeficientes de difusão envolvidos na oxidação eletrocatalítica dos carboidratos foram determinados.
\end{abstract}

This study investigated the electrocatalytic oxidation of fructose, sucrose, glucose, lactose, arabinose and maltose on nanoparticles of cobalt hydroxide electrodeposited on the surface of glassy carbon electrode in alkaline solutions. Cyclic voltammetry (CV), chronoamperometry (CA) techniques and also steady state polarization measurements have been employed. In CV studies, in the presence of carbohydrate the increase of the peak current of the oxidation of cobalt hydroxide is followed by a decrease in the corresponding cathodic current. This indicates that carbohydrates were oxidized by the redox mediator which was immobilized on the electrode surface via an electrocatalytic mechanism. With the use of Laviron's equation, the values of anodic and cathodic electron-transfer coefficients and charge transfer rate constant for the immobilized redox species were determinated as $0.71 \pm 0.03,0.33 \pm 0.03$ and $0.21 \pm 0.02 \mathrm{~s}^{-1}$, respectively. The rate constant, the electron transfer coefficient and the diffusion coefficients involved in the electrocatalytic oxidation of carbohydrates were determined.

Keywords: carbohydrates, electrocatalysis, cobalt hydroxide, modified electrode

\section{Introduction}

Electro-oxidation of organic molecules finds wide application in the development of power sources and sensors. Numerous studies on the anode reaction of direct alcohol fuel cell ${ }^{1-3}$ bear testimony to the former application, while studies on carbohydrate oxidation on different electrodes are aimed at the latter purpose ${ }^{4-13}$ as well as for specific synthetic goals. ${ }^{14-18}$ Oxide electrodes are likely

*e-mail: g.knezhad@gmail.com to be suitable for carbohydrate oxidation because these molecules are expected to get easily adsorbed on the oxide layer by formation of hydrogen bonds via the $\mathrm{OH}$ groups, which facilitate electron transfer. ${ }^{19,20}$

In recent years, oxidation processes at copper, nickel, and nickel hydroxide electrodes in alkaline solution have received considerable attention because of their application to the detection of carbohydrates and related compounds in liquid chromatography $\mathrm{y}^{21-29}$ and capillary electrophoresis ${ }^{30,31}$ systems. The attractiveness of this approach comes from 
the fact that carbohydrates are not generally electroactive at the carbon electrodes commonly used for detection in flow systems. Cobalt hydroxide allows the oxidation to proceed smoothly at constant applied potential. As a result, sensitive detection can be obtained conveniently at cobalt hydroxide modified glassy carbon (CHM-GC) electrodes with simple electrochemical instrumentation.

The purpose of the present work is the detailed investigation of carbohydrates oxidation on CHM-GC in alkaline solution aiming at the elucidation of the kinetics and the derivation of the rate constants. The electrocatalytic oxidation of carbohydrates on this type of electrode is attractive because of interest in sugar-oxygen fuel cell application, as well as sugar sensors for the medical and food industry. ${ }^{32-34}$

\section{Experimental}

All chemicals used were of analytical grade from Merck (Darmstadt, Germany) and were used without further purification. All solutions were prepared with doubly distilled water. Electrochemical measurements were carried out in a conventional three-electrode cell powered by an electrochemical system comprising an AUTOLAB system (PGSTAT12, Eco Chemie, Utrecht, The Netherlands). The system was run on a PC using GPES 4.9 softwares. A saturated calomel electrode (SCE) was a reference electrode. All potentials were measured with respect to the SCE which was positioned as close to the working electrode as possible by means of a Luggin capillary. Films of cobalt hydroxide were formed on the GC electrode with surface area $0.125 \mathrm{~cm}^{2}$ by the method previously reported by Casella. ${ }^{35}$ The modified electrodes were prepared by cycling the potential of the working electrode in the range of -250 to $750 \mathrm{mV}$ (vs. SCE) at a scan rate of $100 \mathrm{mV} \mathrm{s}^{-1}$ for 70 cycles. The surface concentration of cobalt hydroxide was controlled by the number of cycles applied in the deposition process and was electrochemically evaluated in $100 \mathrm{mmol} \mathrm{L}^{-1} \mathrm{NaOH}$ solution. Prior to the modification, the GC electrode was polished with $0.05 \mu \mathrm{m}$ alumina suspension on a polishing micro-cloth and rinsed thoroughly with doubly distilled water. All experiments were performed at room temperature $22 \pm 3{ }^{\circ} \mathrm{C}$.

\section{Results and Discussion}

Figure $1 \mathrm{~A}$ presents 75 consecutive cyclic voltammograms $(\mathrm{CV})$ of a $\mathrm{GC}$ electrode in the presence of $100 \mathrm{mmol} \mathrm{L}^{-1} \mathrm{Na}_{2} \mathrm{CO}_{3}+40 \mathrm{mmol} \mathrm{L}{ }^{-1} \mathrm{NaK}$ tartrate + $4 \mathrm{mmol} \mathrm{L}^{-1} \mathrm{CoCl}_{2}$ at $\mathrm{pH} 11.6$ recorded at a potential sweep rate of $100 \mathrm{mV} \mathrm{s}^{-1}$. The voltammograms are similar to
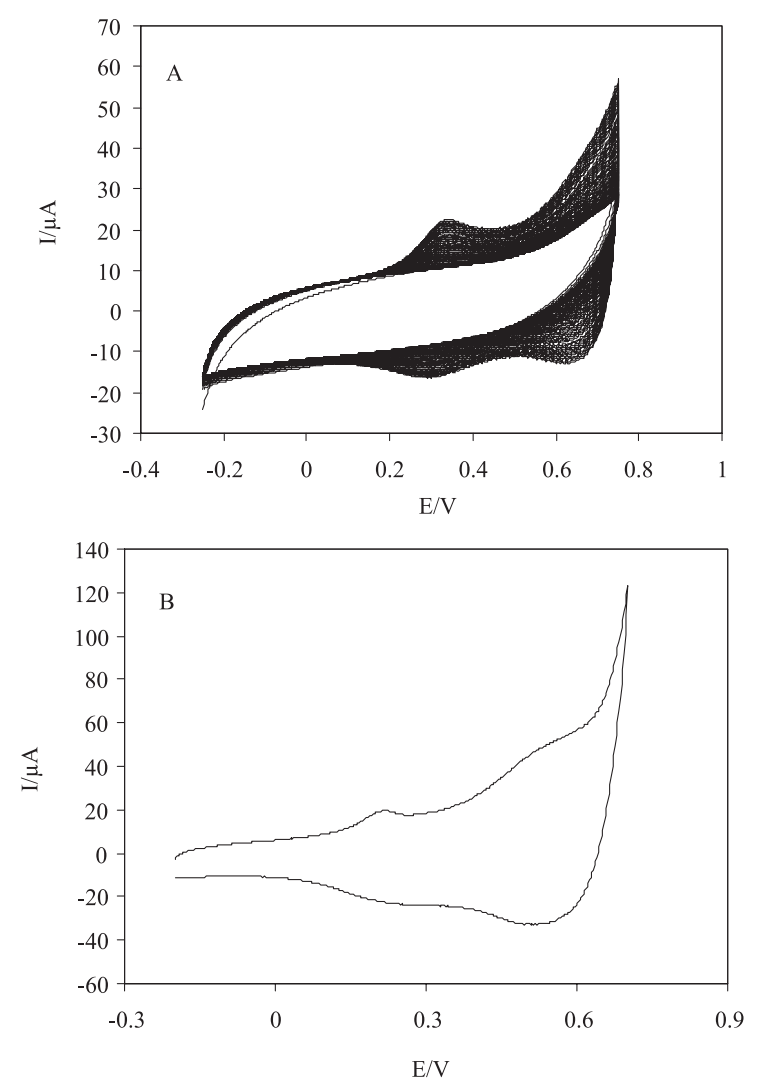

Figure 1. A: Cyclic voltammograms for $4 \mathrm{mmol} \mathrm{L}^{-1} \mathrm{CoCl}_{2}+40 \mathrm{mmol} \mathrm{L}^{-1}$ $\mathrm{Na}-\mathrm{K}$ tartrate $+100 \mathrm{mmol} \mathrm{L}^{-1} \mathrm{Na}_{2} \mathrm{CO}_{3}$ using a GC electrode; the potential was scanned continuously at $100 \mathrm{mV} \mathrm{s}^{-1}$ between -250 and $750 \mathrm{mV}$. B: Cyclic voltamogram of CHM-GC in $100 \mathrm{mmol} \mathrm{L}^{-1} \mathrm{NaOH}$ solution in the range of -200 to $690 \mathrm{mV} / \mathrm{SCE}$ with a sweep rate $100 \mathrm{mV} \mathrm{s}^{-1}$.

those reported in literature. ${ }^{35,36}$ Figure $1 \mathrm{~B}$ shows a cyclic voltammogram of CHM-GC electrode in $100 \mathrm{mmol} \mathrm{L}^{-1}$ $\mathrm{NaOH}$ solution in the range of -200 to $690 \mathrm{mV}$ recorded at a potential sweep rate of $100 \mathrm{mV} \mathrm{s}^{-1}$. It shows anodic peaks located at 225 and $550 \mathrm{mV} / \mathrm{SCE}$ which are attributed to $\mathrm{Co}(\mathrm{II}) / \mathrm{Co}$ (III) and $\mathrm{Co}(\mathrm{III}) / \mathrm{Co}(\mathrm{IV})$ redox transitions associated with different cobalt oxide species on the electrode surface. ${ }^{37,38}$ The cathodic peaks at 186 and 522 correspond to the reduction of various cobalt oxide species formed during the positive sweep.

Figure 2A represents cyclic voltammograms of the CHM-GC electrode in $100 \mathrm{mmol} \mathrm{L}^{-1} \mathrm{NaOH}$ solution recorded at different potential sweep rates in a wide range of $2-150 \mathrm{mV} \mathrm{s}^{-1}$. The peak-to-peak potential separation (at the potential sweep rate of $20 \mathrm{mV} \mathrm{s}^{-1}$ ) is $51 \mathrm{mV}$. The voltammograms shown are similar to those previously reported $^{36}$ and the redox transition involved is attributed to the presence of Co (III)/Co (IV) species. The peak-topeak potential separation deviates from the theoretical value of zero and increases at higher potential sweep rates. This result indicates a limitation in the charge-transfer kinetics, which is due to: $(i)$ chemical interactions between 
the electrolyte ions and the modifier film, (ii) dominance of electrostatic factors, (iii) the lateral interactions of the redox couples present on the surface and/or (iv) nonequivalent sites present in the film. Laviron derived general expressions for the linear potential sweep voltammetric response for the case of surface-confined electro-reactive species at small concentrations. ${ }^{39}$ The expressions for peakto-peak potential separations, $(\Delta \mathrm{Ep})>200 / \mathrm{n} \mathrm{mV}$ where $\mathrm{n}$ is the number of exchanged electrons, are as follows:

$$
\begin{aligned}
& E_{p a}=E^{0}+X \ln \left[\frac{\left(1-\alpha_{s}\right)}{m}\right] \\
& E_{p c}=E^{0}+Y \ln \left[\frac{\alpha}{m}\right]
\end{aligned}
$$

$$
\ln \mathrm{k}_{\mathrm{s}}=\alpha_{\mathrm{s}} \ln \left(1-\alpha_{\mathrm{s}}\right)+\left(1-\alpha_{\mathrm{s}}\right) \ln \alpha_{\mathrm{s}}-\ln \left(\frac{\mathrm{RT}}{\mathrm{nFv}}\right)-
$$

$$
\alpha_{\mathrm{s}}\left(1-\alpha_{\mathrm{s}}\right) \frac{\mathrm{nF} \Delta \mathrm{E}_{\mathrm{p}}}{\mathrm{RT}}
$$

where $\mathrm{X}=\mathrm{RT} /(1-\alpha) \mathrm{nF}, \mathrm{Y}=\mathrm{RT} / \alpha \mathrm{nF}, \mathrm{m}=(\mathrm{RT} / \mathrm{F})\left(\mathrm{k}_{\mathrm{s}} / \mathrm{n} v\right)$, $\mathrm{E}_{\mathrm{pa}}$ and $\mathrm{E}_{\mathrm{pc}}$ are the anodic and cathodic peak potentials, respectively, and $\alpha_{s}, \mathrm{k}_{\mathrm{s}}$ and $v$ are the electron-transfer coefficient, apparent charge-transfer rate constant and
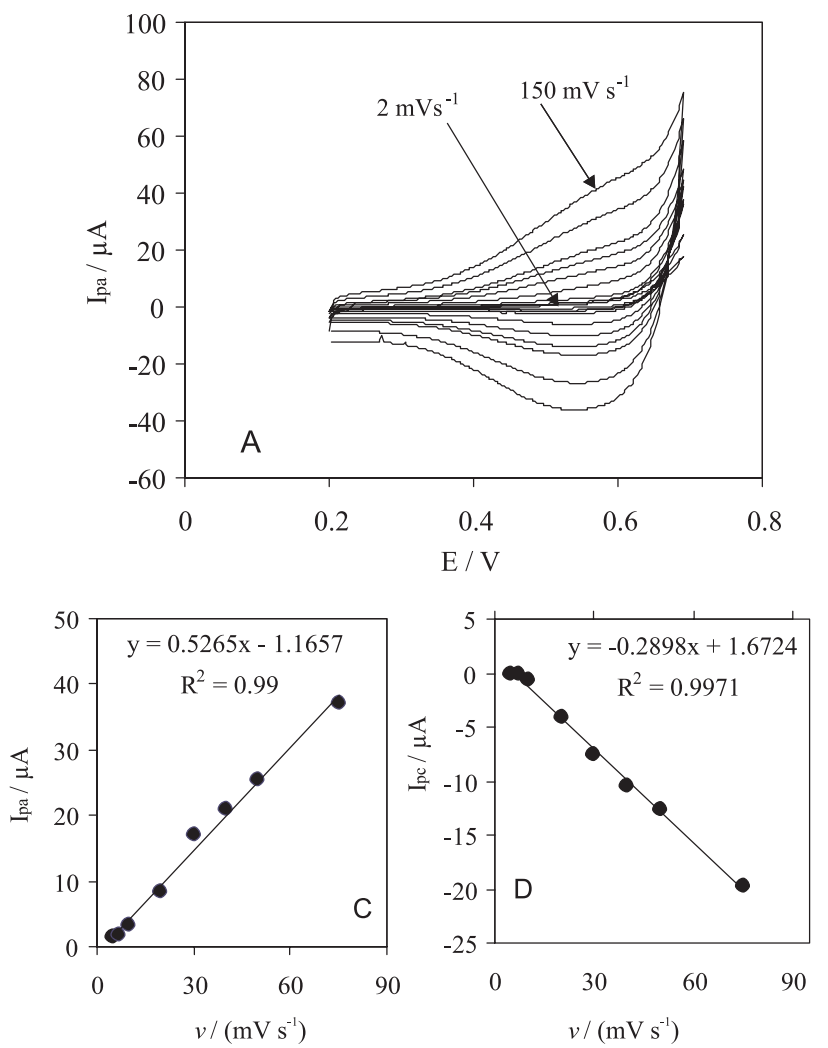

potential sweep rate, respectively. From these expressions, $\alpha_{\mathrm{s}}$ can be determined by measuring the variation of the peak potential with respect to the potential sweep rate, and $\mathrm{k}_{\mathrm{s}}$ can be determined for electron transfer between the electrode and the surface deposited layer by measuring the $\Delta \mathrm{Ep}$ values. Figure $2 \mathrm{~B}$ and Table1 show the variations of $\left(\mathrm{E}_{\mathrm{p}}\right)$ with respect to the logarithm $v$ from the cyclic voltammograms recorded for CHM-GC electrode in $100 \mathrm{mmol} \mathrm{L}^{-1} \mathrm{NaOH}$ solution at potential sweep rates of 2-900 mV s${ }^{-1}$ for cathodic (b1) and anodic peak (b2). It can be observed that for potential sweep rates of $150-900 \mathrm{mV} \mathrm{s}^{-1}$, the values of $\left(\mathrm{E}_{\mathrm{p}}\right)$ are proportional to the logarithm of the potential sweep rate indicated by Laviron. Using the plot and equations 1 and 3, the values of $\alpha_{\mathrm{s}, \mathrm{a}}$ (anodic electron-transfer coefficient) was determined as $0.71 \pm 0.03$. In addition, using the inset of Figure $2 \mathrm{~B}$ and equations 2 and 3 , the values of $\alpha_{\mathrm{s}, \mathrm{c}}, \mathrm{k}_{\mathrm{s}}$ was determined as $0.34 \pm 0.03$ and $(0.21 \pm 0.02) \mathrm{s}^{-1}$, respectively. Figure 2A presents typical CVs of a CHM-GC electrode in $100 \mathrm{mmol} \mathrm{L}^{-1} \mathrm{NaOH}$ solutions at various potential sweep rates of 2-150 $\mathrm{mV} \mathrm{s}^{-1}$. The peak's currents are proportional to sweep rates in the range of $2-75 \mathrm{mV} \mathrm{s}^{-1}$, Figure 2(C) and (D), pointing to the electrochemical activity of the surface redox couple. From the slope of this line and using:
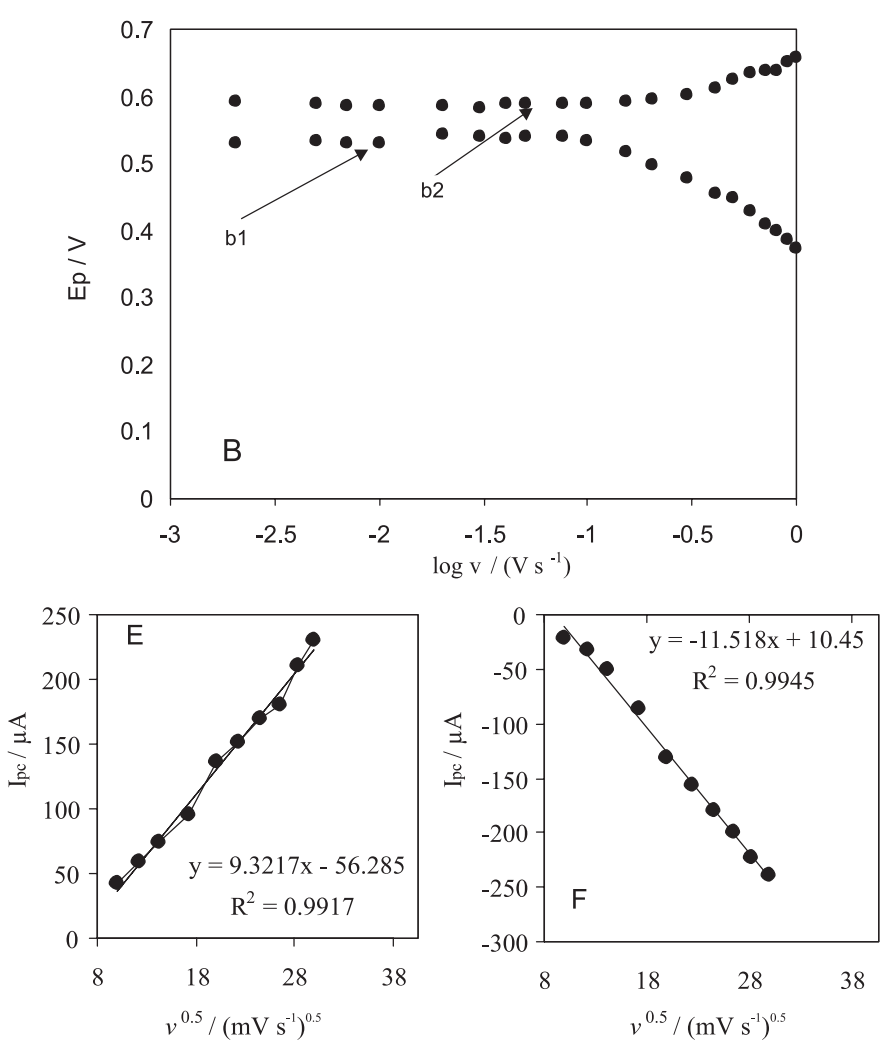

Figure 2. A: Cyclic voltammograms of CHM-GC electrode in $100 \mathrm{mmol} \mathrm{L}{ }^{-1}$ sodium hydroxide solutions. Potential sweep rates from inner to outer are: 2 , $5,7,10,20,30,40,50,75,100,150 \mathrm{mV} \mathrm{s}^{-1}$. B: Plot of E versus $\log v$ for cyclic voltammograms depicted in (A) for anodic peaks (b1) and cathodic peaks (b2). (C-F): The dependency of anodic (C, E) and cathodic (D, F) peak currents on the potential sweep rate at lower values of 2-75 $\mathrm{mV} \mathrm{s}{ }^{-1}(\mathrm{C}, \mathrm{E})$ and on the square roots of sweep rate at higher values of $100-900 \mathrm{mV} \mathrm{s}^{-1}(\mathrm{D}, \mathrm{F})$. 
Table 1. Values of the scan rate $(v), \mathrm{E}_{\mathrm{pa}}$ and $\mathrm{E}_{\mathrm{pc}}$ obtained from cyclic voltammetry method in $\mathrm{NaOH} 100 \mathrm{mmol} \mathrm{L}^{-1}$

\begin{tabular}{|c|c|c|}
\hline$v /\left(\mathrm{mV} \mathrm{s}^{-1}\right)$ & Epa & Epc \\
\hline 2 & 0.592 & 0.53 \\
\hline 5 & 0.59 & 0.532 \\
\hline 7 & 0.586 & 0.53 \\
\hline 10 & 0.585 & 0.542 \\
\hline 20 & 0.5851 & 0.539 \\
\hline 30 & 0.5817 & 0.537 \\
\hline 40 & 0.588 & 0.541 \\
\hline 50 & 0.5887 & 0.539 \\
\hline 75 & 0.588 & 0.532 \\
\hline 100 & 0.5886 & 0.520 \\
\hline 150 & 0.592 & 0.498 \\
\hline 200 & 0.5958 & 0.478 \\
\hline 300 & 0.603 & 0.456 \\
\hline 400 & 0.613 & 0.447 \\
\hline 500 & 0.6256 & 0.43 \\
\hline 600 & 0.633 & 0.408 \\
\hline 700 & 0.637 & 0.398 \\
\hline 800 & 0.639 & 0.386 \\
\hline 900 & 0.65 & 0.380 \\
\hline 1000 & 0.659 & 0.373 \\
\hline
\end{tabular}

$I_{p}=\left(\frac{n^{2} F^{2}}{4 R T}\right) v A \Gamma^{*}$

where $\Gamma^{*}$ is the surface coverage of the redox species and $v$ being the potential sweep rate ${ }^{40}$ and taking average of both cathodic and anodic results, $\Gamma^{*}$ values of around $1.98 \times 10^{-9} \mathrm{~mol} \mathrm{~cm}^{-2}$ have been derived. In the high range of sweep rates this dependency is of square root form, Figures $2 \mathrm{E}$ and $2 \mathrm{~F}$, indicating the dominance of the diffusion controlled processes.

Figure $3 \mathrm{~A}$ illustrates cyclic voltammograms of $0.8 \mathrm{mmol} \mathrm{L}^{-1}$ glucose using the CHM-GC electrode recorded at different potential sweep rates. Figure $3 \mathrm{~B}$ indicates that the anodic peak currents increased linearly with the square root of the potential sweep rate, which indicates a mass transfercontrolling process of oxidation via diffusion. In addition the value of the electron-transfer coefficient for the reaction can be obtained from the following equation: ${ }^{41}$

$\mathrm{E}_{\mathrm{p}}=\left(\frac{\mathrm{RT}}{2 \alpha \mathrm{F}}\right) \ln v+$ constant

This is valid for a totally irreversible diffusioncontrolled process. Using the dependency of anodic peak potential on the neperian logarithm of the potential sweep rate (Figure 3C), the value of the electron-transfer coefficient was obtained as $(0.59 \pm 0.03)$. Tafel slope is $(41.99 \pm 0.03)$. On the basis of the slopes of the linear dependency of the anodic peak currents on the square root of the potential sweep rates (Figure 3B), and the Randles-Sevcik equation: ${ }^{40}$

$\mathrm{I}_{\mathrm{p}}=\left(2.99 \times 10^{5}\right) \alpha^{1 / 2} \mathrm{n}^{3 / 2} \mathrm{AC}^{*} \mathrm{D}^{1 / 2} \mathrm{v}^{1 / 2}$

where $I_{p}$ is the peak current, $A$ is the electrode surface area, $\mathrm{D}$ is the diffusion coefficient, and $\mathrm{C}^{*}$ is the bulk concentration of carbohydrates, the diffusion coefficient for glucose was calculated to be $(9.1 \pm 0.03) \times 10^{-6} \mathrm{~cm}^{2} \mathrm{~s}^{-1}$.

Figure 4A presents the CVs of CHM-GC both in the absence (a) and $0.3 \mathrm{mmol} \mathrm{L}^{-1}$ (low concentration) glucose in $100 \mathrm{mmol} \mathrm{L}^{-1} \mathrm{NaOH}$ solution (b). At CHM-GC electrode, oxidation of glucose resulted in a typical electrocatalytic response. In the presence of glucose, it was observed that the anodic current and the associated anodic charge increased drastically, while the cathodic current and the corresponding charge decreased. In the presence of glucose the ratio $\mathrm{i}_{\mathrm{pa}} / \mathrm{i}_{\mathrm{pc}}$ was 82.6 when in absence of it this ratio was decreased to 23.2. This result indicates that glucose is oxidized by active Co(IV) moiety through a cyclic mediation redox process. Cobalt species are immobilized on the electrode surface, and the one with a higher valence oxidizes to Co(IV) via a chemical reaction followed by generation of low-valence cobalt (Co(III) species). Along this line, the high-valence oxide is regenerated through the external electrical circuit. Accordingly, glucose is oxidized via an $\mathrm{EC}^{\prime}$ mechanism.

Figures $4 \mathrm{~B}, \mathrm{C}$ show that upon increasing glucose concentration its irreversible oxidation develops in the region of the electrochemical formation of Co(IV). Thus, it is likely that the electro-generated Co(IV) species is the active moiety which efficiently speeds up the oxidation of carbohydrates. Any increase in the concentration of carbohydrates causes a proportional almost linear enhancement of the anodic wave. It is worthy to emphasize that the anodic formation of Co(IV) seems to be an irreversible process. Also, plotting the current function (peak current divided by the square root of the potential sweep rate) against the square root of the potential sweep rate (Figure 5) revealed negative slope confirming the electrocatalytic nature of the process.

The redox transition of cobalt species present in the film is:

$\mathrm{Co}(\mathrm{III}) \frac{\mathrm{k}_{+1}(\mathrm{E})}{\mathrm{k}_{-1}(\mathrm{E})}-\mathrm{Co}(\mathrm{IV})+\mathrm{e}$ 

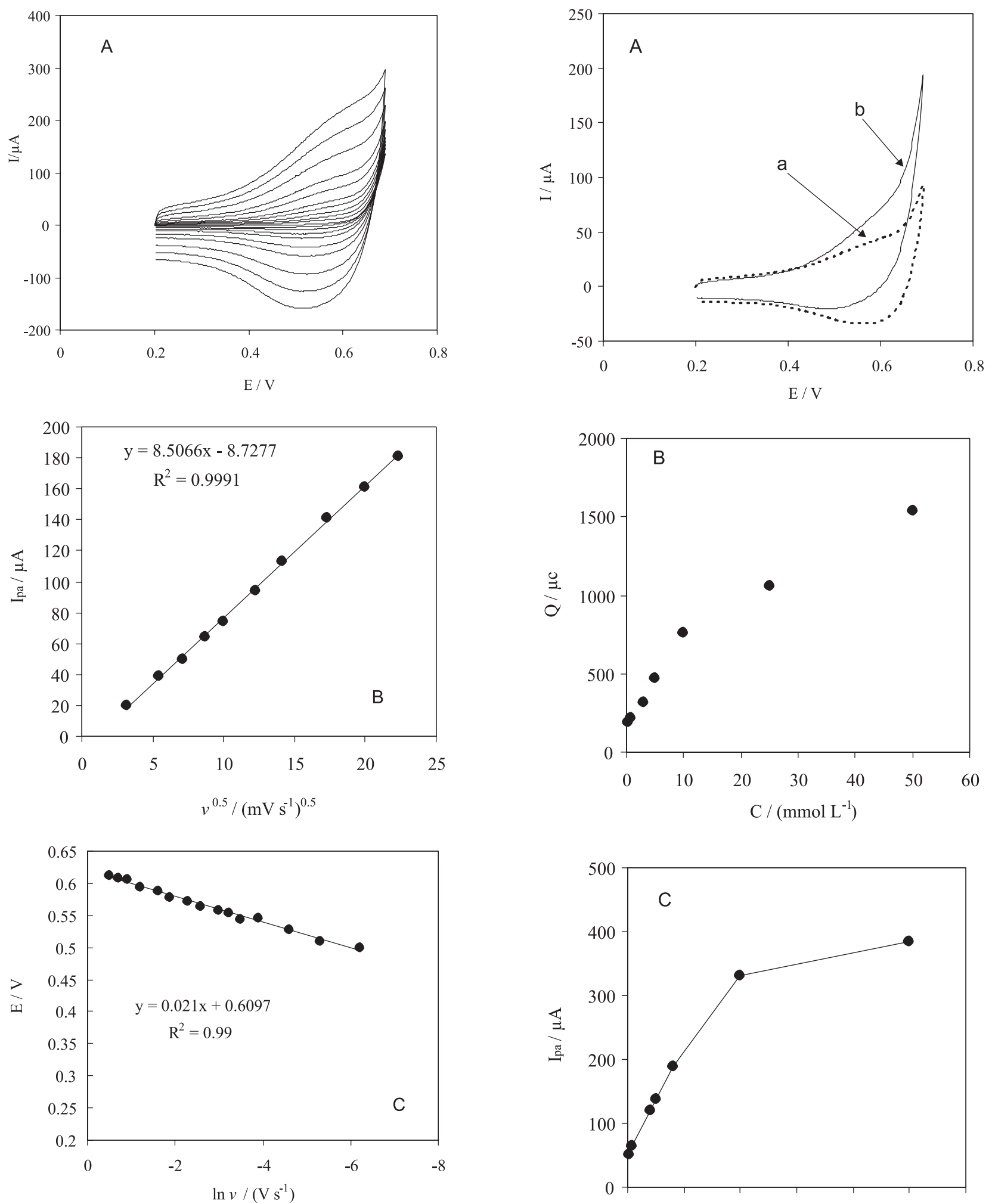

Figure 3. A: Cyclic voltammograms of the CHM-GC electrode in $100 \mathrm{mmol} \mathrm{L}^{-1} \mathrm{NaOH}$ solution in the presence of $0.8 \mathrm{mmol} \mathrm{L}^{-1}$ glucose at various potential sweep rates of $5,10,50,75,100,150,200,300,400$, $500,600 \mathrm{mV} \mathrm{s}^{-1}$. Inset A: typical cyclic voltammograms of the CHM electrode in $100 \mathrm{mmol} \mathrm{L}^{-1} \mathrm{NaOH}$ solution at sweep rate $50 \mathrm{mV} \mathrm{s}^{-1}$. B: Dependence of anodic peak current during the forward sweep on the square roots of potential sweep rate. C: Dependence of the peak potential on $\ln v$ for the oxidation of glucose at CHM-GC electrode obtained from the data of panel (A).

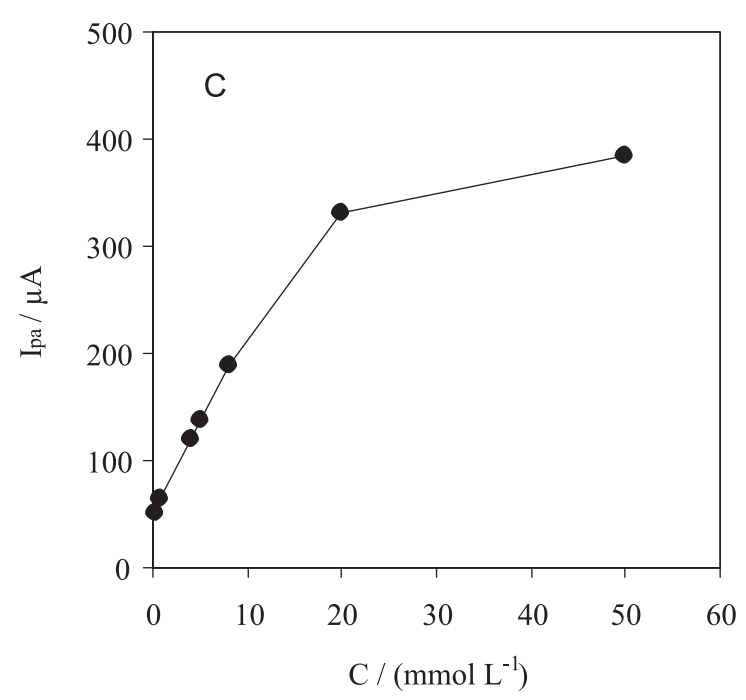

Figure 4. A: Cyclic voltammograms of the CHM-GC electrode in $100 \mathrm{mmol} \mathrm{L}^{-1} \mathrm{NaOH}$ solution in the absence (a) and the presence (b) $0.3 \mathrm{mmol} \mathrm{L}^{-1}$ of glucose. Potential sweep rate was $100 \mathrm{mV} \mathrm{s}^{-1}$. B: Dependence of the charge under the anodic peak on the concentration of glucose in solution. C: Dependence of the anodic peak current electrooxidation on glucose concentration. 


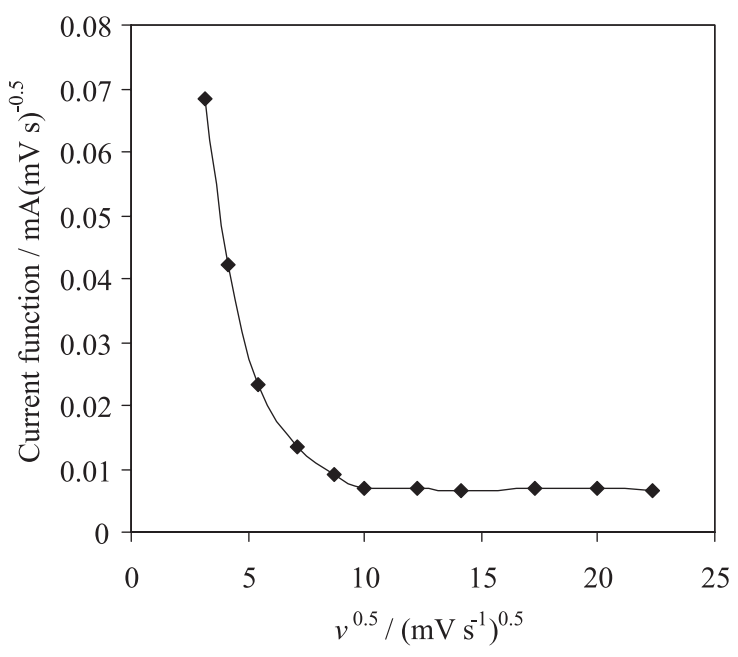

Figure 5. Current function $v s$. $v^{0.5}$ for $100 \mathrm{mmol} \mathrm{L}^{-1} \mathrm{NaOH}$ solutions in the presence of $3 \mathrm{mmol} \mathrm{L}^{-1}$ glucose.

And glucose is oxidized on the modified surface via the following reaction:

$\mathrm{Co}(\mathrm{IV})+$ glucose $\stackrel{\mathrm{k}_{2}(\mathrm{E})}{\longrightarrow}$ Intermediate $+\mathrm{Co}(\mathrm{III})$

$\mathrm{Co}(\mathrm{IV})+$ Intermediate $\stackrel{\mathrm{k}_{3}(\mathrm{E})}{\longrightarrow}$ Product $+\mathrm{Co}(\mathrm{III})$

The oxidation process on the CHM-GC electrode exhibited similar electrocatalytic responses for other carbohydrates, fructose, arabinose, lactose, maltose, sucrose; thereby exhibiting its capability for selective oxidation of carbohydrates.

Chronoamperometry, as well as cyclic voltammetry, has been employed for the investigation of the processes occurring via $\mathrm{E}_{\mathrm{r}} \mathrm{C}_{\mathrm{i}}$ mechanism. ${ }^{40}$ Double steps chronoamperograms were recorded by setting the working electrode potentials to desired values and were used to measure the catalytic rate constant on the modified surface. Figure 6A shows double steps chronoamperograms for the modified electrode in the absence (a) and presence (b: 0.8, c: 3, d: 5, e: 10, f: 25 and $50 \mathrm{mmol} \mathrm{L}^{-1}$ ) of glucose over a concentration range of $0.8-50 \mathrm{mmol} \mathrm{L}^{-1}$. The applied potential steps were 230 and $560 \mathrm{mV}$, respectively. The plot of net current versus time $\mathrm{e}^{-0.5} / \mathrm{s}^{-0.5}$ which has been obtained by removing the background current by the point-by-point subtraction method gives a straight line that level off around $13 \mu \mathrm{A}$, Figure $6 \mathrm{~B}$. This indicates that the transient current must be controlled by a diffusion process. The transient current is due to catalytic oxidation of glucose and the current increases as the glucose concentration is raised. No significant cathodic current is observed when the electrolysis potential is stepped to $230 \mathrm{mV} / \mathrm{SCE}$ indicating the irreversible nature of the oxidation of carbohydrates by using the slopes of these lines; we can obtain the diffusion coefficients of the glucose according to the Cottrell equation: ${ }^{40}$
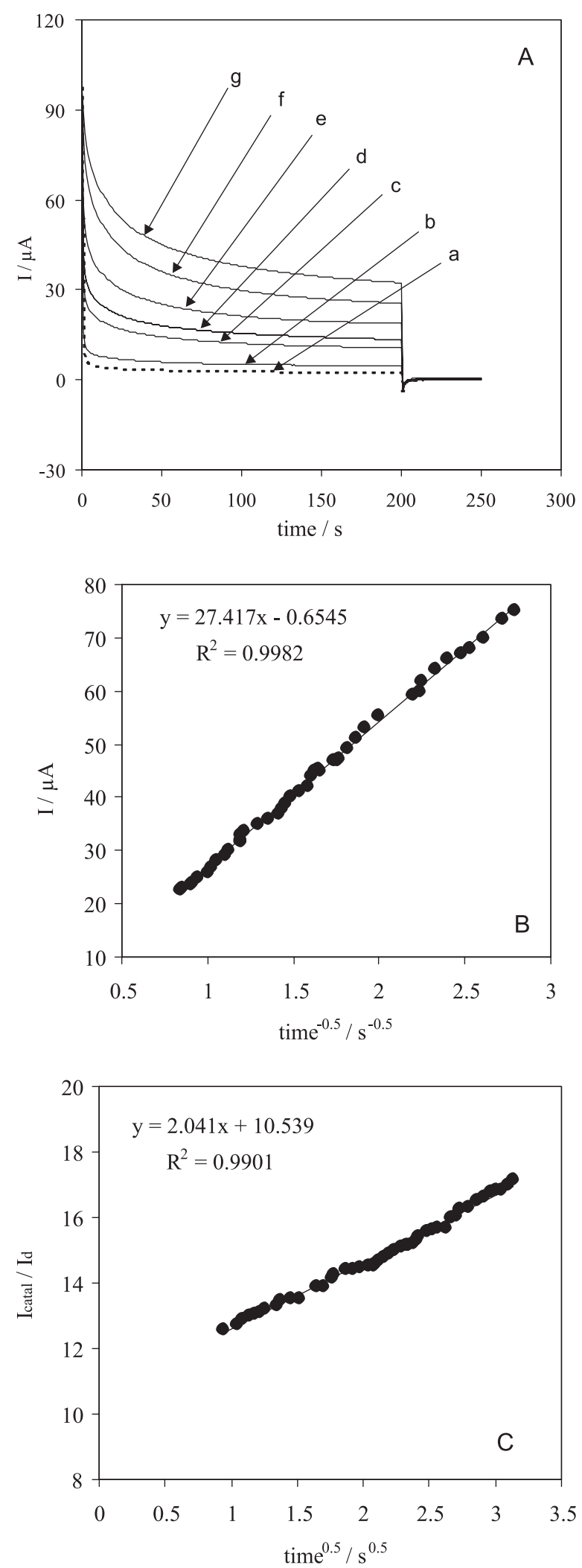

Figure 6. A: Double steps chronoamperograms of CHM-GC electrode in the absence (a) and the presence of 0.8 (b), 3 (c), 5 (d), 10 (e), 25 (f) and $50 \mathrm{mmol} \mathrm{L}^{-1}(\mathrm{~g})$ glucose in $100 \mathrm{mmol} \mathrm{L}^{-1} \mathrm{NaOH}$ solution. Potential steps were $560 \mathrm{mV}$ and $230 \mathrm{mV}$, respectively. B: Dependence of transient current on time $-0.5 / \mathrm{s}^{-0.5}$. C: Dependence of $\mathrm{I}_{\text {catal }} / \mathrm{I}_{\mathrm{d}}$ on time $\mathrm{e}^{0.5} / \mathrm{s}^{0.5}$ derived from the data of chronoamperograms of (a) and (g) in main panel. 
$\mathrm{I}=\mathrm{nFAD}{ }^{1 / 2} \mathrm{C}^{*} \pi^{-1 / 2} \mathrm{t}^{-1 / 2}$

where D is the diffusion coefficient, and $\mathrm{C}^{*}$ is the bulk concentration. The mean value of the diffusion coefficients of glucose was found to be $(6.49 \pm 0.02) \times 10^{-6} \mathrm{~cm}^{2} \mathrm{~s}^{-1}$. These values are in agreement with those obtained using cyclic voltammetry (Figure 3 ).

The rate constants of the reactions of glucose and the ensued intermediates with the redox sites of the CHM-GC electrode can be derived from the chronoamperograms according to: ${ }^{40}$

$\frac{I_{\text {catal }}}{I_{d}}=\lambda^{1 / 2}\left[\pi^{1 / 2} \operatorname{erf}\left(\lambda^{1 / 2}\right)+\frac{\exp (-\lambda)}{\lambda^{1 / 2}}\right]$

where $I_{\text {catal }}$ is the catalytic current in the presence of glucose, $I_{d}$ the limiting current in the absence of glucose and $\lambda=\mathrm{kCt}(\mathrm{k}, \mathrm{C}$ and $\mathrm{t}$ are the catalytic rate constant, bulk concentration of glucose and the elapsed time, respectively) is the argument of the error function. For $\lambda>1.5$, erf $\left(\lambda^{1 / 2}\right)$ almost equals unity and equation 11 reduces to:

$\frac{\mathrm{I}_{\text {catal }}}{\mathrm{I}_{\mathrm{d}}}=\lambda^{1 / 2} \pi^{1 / 2}=\pi^{1 / 2}(\mathrm{kCt})^{1 / 2}$

From the slope of the $I_{\text {catal }} / I_{d}$ plot the value of $k$ at a given concentration of glucose is derived. The mean value of $\mathrm{k}$ in the concentration range of $0.8-50 \mathrm{mmol} \mathrm{L}^{-1}$ was found to be $(2.64 \pm 0.03) \times 10^{4} \mathrm{~cm}^{3} \mathrm{~mol}^{-1} \mathrm{~s}^{-1}$. It should be pointed out that $\mathrm{k}$ is either $\mathrm{k}_{2}$ or $\mathrm{k}_{3}$ whichever is smaller.

Similar chronoamperograms were collected for fructose, arabinose, lactose, maltose and sucrose. The values of D and $\mathrm{k}$ obtained according to the method described above for these carbohydrates were reported in Table 2. Figure 7 presents chronoamperograms of other carbohydrates at $25 \mathrm{mmol} \mathrm{L}^{-1}$. Herein, it can be qualitatively deduced from the cyclic voltammograms depicted in Figure 8 that the CHM-GC electrode has a catalytic activity toward the carbohydrates in the relation of lactose $>$ glucose $\geq$ fructosemaltose $>$ arabinose $>$ sucrose. The fact that lactose exhibited a slightly more facile oxidation at the cobalt hydroxide electrode than glucose suggested that the primary functionality required for the process might be the hydroxy group or, more likely, several adjacent hydroxy groups.

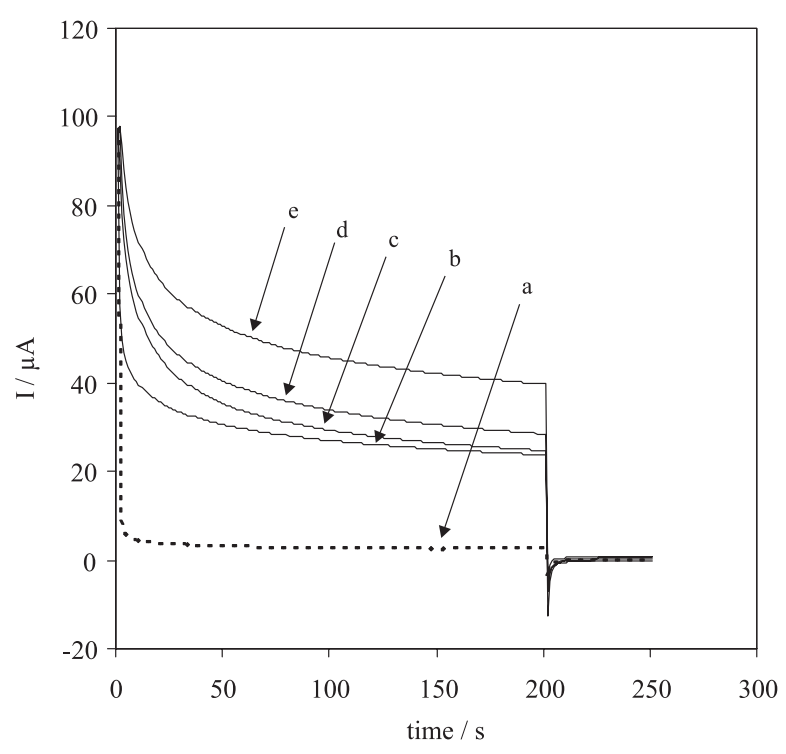

Figure 7. Chronoamperograms of the CHM-GC electrode in $100 \mathrm{mmol} \mathrm{L}^{-1}$ $\mathrm{NaOH}$ solution in the absence (a) and the presence of $25 \mathrm{mmol} \mathrm{L}^{-1}$ of sucrose (b), arabinose(c), fructose (d), lactose (e). Potential steps were $560 \mathrm{mV}$ and $230 \mathrm{mV}$, respectively.

The rate laws for the reactions 7 and 8 have the forms of:

$\mathrm{v}_{1}=\mathrm{k}_{1} \Gamma \theta_{\mathrm{III}}-\mathrm{k}_{-1} \Gamma \theta_{\mathrm{IV}}$

$v_{2}=\mathrm{k}_{2} \Gamma \theta_{\mathrm{IV}} \mathrm{C}_{\mathrm{m}}$

where $\Gamma$ is the total number of adsorption sites per unit area of the electrode surface, $\theta$ 's represent the fractional surface coverage of different cobalt valence states and $\mathrm{C}_{\mathrm{m}}$ is the bulk concentration of glucose. With only the 3 and 4 valence states of cobalt prevailing one has:

$\theta_{\mathrm{III}}+\theta_{\mathrm{IV}}=1$

Table 2. The electrocatalytic reaction rate constants (k), the diffusion coefficients (D) and the electron transfer coefficient ( $\alpha$ ), Tafel slop (b) for the carbohydrates

\begin{tabular}{lcccc}
\hline Carbohydrate & $\mathrm{k} /\left(\mathrm{cm}^{3} \mathrm{~mol}^{-1} \mathrm{~s}^{-1}\right)$ & $\mathrm{D} /\left(\mathrm{cm}^{2} \mathrm{~s}^{-1}\right)$ & $\alpha$ & $\mathrm{b}$ \\
\hline Glucose & $(2.64 \pm 0.03) \times 10^{4}$ & $(6.49 \pm 0.02) \times 10^{-6}$ & $0.59 \pm 0.03$ & $41.99 \pm 0.02$ \\
Fructose & $(3.20 \pm 0.03) \times 10^{4}$ & $(5.22 \pm 0.03) \times 10^{-6}$ & $0.51 \pm 0.02$ & $48.57 \pm 0.02$ \\
Arabinose & $(1.11 \pm 0.05) \times 10^{4}$ & $(3.14 \pm 0.03) \times 10^{-6}$ & $0.53 \pm 0.02$ & $46.74 \pm 0.02$ \\
Lactose & $(2.11 \pm 0.02) \times 10^{5}$ & $(7.44 \pm 0.03) \times 10^{-6}$ & $0.61 \pm 0.02$ & $40.61 \pm 0.02$ \\
Sucrose & $(1.02 \pm 0.03) \times 10^{4}$ & $(4.26 \pm 0.05) \times 10^{-6}$ & $0.45 \pm 0.04$ & $55.05 \pm 0.02$ \\
Maltose & $(6.64 \pm 0.02) \times 10^{4}$ & $(5.71 \pm 0.02) \times 10^{-6}$ & $0.60 \pm 0.03$ & $40.72 \pm 0.03$ \\
\hline
\end{tabular}


And the rates of changes of their surface coverages as well as that of the intermediate compounds are:

$\frac{\mathrm{d} \theta_{\text {III }}}{\mathrm{dt}}=-\frac{\mathrm{d} \theta_{\mathrm{IV}}}{\mathrm{dt}}=-\mathrm{k}_{1} \theta_{\mathrm{III}}+\mathrm{k}_{-1} \theta_{\mathrm{IV}}+\mathrm{k}_{2} \theta_{\mathrm{IV}} \mathrm{C}_{\mathrm{m}}+\mathrm{k}_{3} \theta_{\mathrm{IV}} \mathrm{C}_{\mathrm{i}}$

$\frac{\mathrm{dc}_{\mathrm{i}}}{\mathrm{dt}}=\mathrm{k}_{2} \theta_{\mathrm{IV}} \mathrm{C}_{\mathrm{m}}-\mathrm{k}_{3} \theta_{\mathrm{IV}} \mathrm{C}_{\mathrm{i}}$

where $\mathrm{C}_{\mathrm{i}}$ is the concentration of the intermediate. Assuming that the steady state dominates:

$\frac{\mathrm{d} \theta_{\mathrm{III}}}{\mathrm{dt}}=-\frac{\mathrm{d} \theta_{\mathrm{IV}}}{\mathrm{dt}}=0$

$\frac{\mathrm{dC}_{\mathrm{i}}}{\mathrm{dt}}=0$

One arrives at the values if the coverages:

$\theta_{\text {III }}=\left(\frac{\mathrm{k}_{-1}+2 \mathrm{k}_{2} \mathrm{C}_{\mathrm{m}}}{\mathrm{k}_{1}+\mathrm{k}_{-1}+2 \mathrm{k}_{2} \mathrm{C}_{\mathrm{m}}}\right)$

$\theta_{\mathrm{IV}}=\left(\frac{\mathrm{k}_{1}}{\mathrm{k}_{1}+\mathrm{k}_{-1}+2 \mathrm{k}_{2} \mathrm{C}_{\mathrm{m}}}\right)$

And subsequently:

$\mathrm{v}_{1}=\left(\frac{2 \mathrm{k}_{1} \Gamma \mathrm{k}_{2} \mathrm{C}_{\mathrm{m}}}{\mathrm{k}_{1}+\mathrm{k}_{-1}+2 \mathrm{k}_{2} \mathrm{C}_{\mathrm{m}}}\right)$

On the basis of this rate equation the faradic current will be:

$\mathrm{i}_{\mathrm{f}}=\left(\frac{2 \mathrm{FAk}_{1} \Gamma \mathrm{k}_{2} \mathrm{C}_{\mathrm{m}}}{\mathrm{k}_{1}+\mathrm{k}_{-1}+2 \mathrm{k}_{2} \mathrm{C}_{\mathrm{m}}}\right)$

where $\mathrm{A}$ is the surface area of the electrode and the rate constants $\mathrm{k}_{1}$ and $\mathrm{k}_{-1}$ are obviously potential dependent and are of the forms:

$\mathrm{k}_{1}(\mathrm{E})=\mathrm{k}^{0}{ }_{1} \exp \left[\frac{\alpha \mathrm{nFE}}{\mathrm{RT}}\right]$

$\mathrm{k}_{-1}(\mathrm{E})=\mathrm{k}^{0}{ }_{-1} \exp \left[\frac{(\alpha-1) \mathrm{nFE}}{\mathrm{RT}}\right]$

where $\mathrm{k}^{\mathrm{o}}$ 's are the chemical rate constants measured at $\mathrm{E} / \mathrm{SCE}=0$ with $\alpha$ being the anodic transfer coefficient and other parameters have their usual meanings. Equation 23 is well suited for the calculation of rate constants and the validity test of the kinetics and mechanism of the oxidation process.
The pseudo-steady state polarization curves of the electro-oxidation of glucose on CHM-GC electrode at a number of glucose concentrations are presented in Figure 9. The oxidation process was found to begin at nearly $400 \mathrm{mV} / \mathrm{SCE}$ and to reach a plateau at $615 \mathrm{mV} / \mathrm{SCE}$ while the oxygen evolution starts at still higher potentials. In the course of reaction the coverage of Co(IV) increases and reaches a saturation (steady state) level and the oxidation current follows accordingly. According to equation 23 the plots of the inverse of current against the inverse of glucose concentration should be linear:

$\mathrm{i}_{\mathrm{f}}{ }^{-1}=\left(\mathrm{FAk}_{1} \Gamma\right)^{-1}+\left[\frac{\mathrm{k}_{1}+\mathrm{k}_{-1}}{2 \mathrm{FAk}_{1} \mathrm{k}_{2} \Gamma}\right] \mathrm{c}_{\mathrm{m}}{ }^{-1}$

Figure 10A presents the $\mathrm{I}^{-1}$ versus $\mathrm{C}_{\mathrm{m}}^{-1}$ dependencies where straight lines at various potentials have been obtained. Both the intercepts and slopes of the straight lines appearing in this figure were potential dependent. The slopes are plotted against $\exp (-\mathrm{nFE} / \mathrm{RT})$ with $\mathrm{n}=1$ and the graph is presented in Figure 10B. Using this graph along
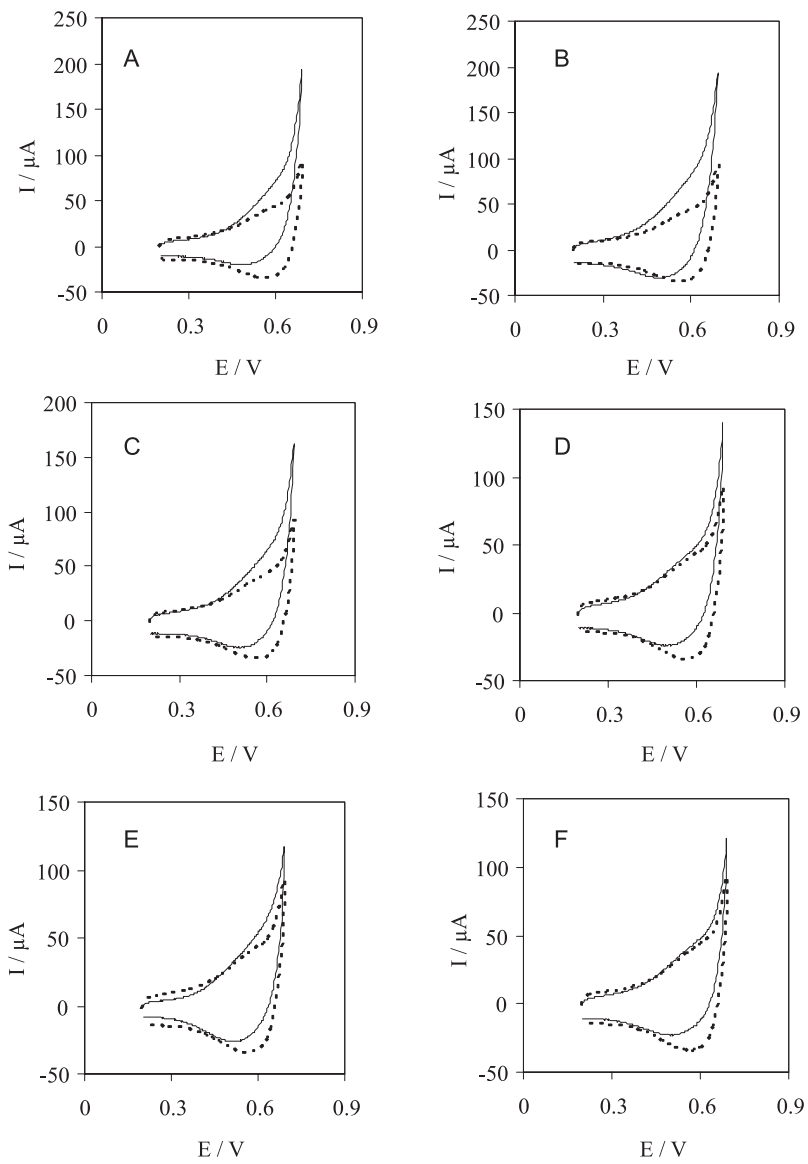

Figure 8. Cyclic voltammograms of the CHM-GC electrode in $100 \mathrm{mmol} \mathrm{L}^{-1} \mathrm{NaOH}$ solution in the absence (---) and the presence of $0.8 \mathrm{mmol} \mathrm{L}^{-1}$ (-), A: glucose, B: fructose, C: arabinose, D: sucrose, E: lactose, F: maltose. Potential sweep rate was $100 \mathrm{mV} \mathrm{s}^{-1}$. 


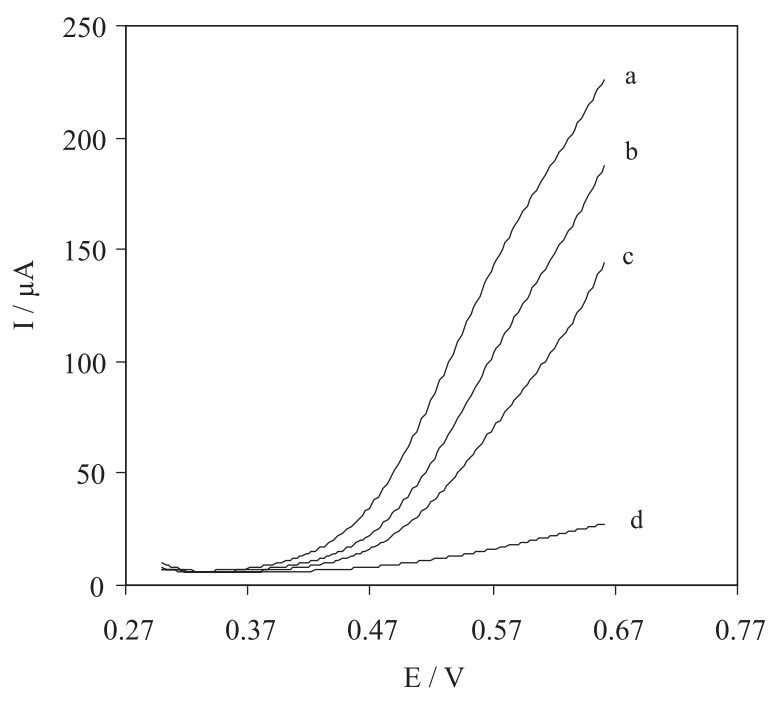

Figure 9. Typical pseudo-steady state polarization curves of CHM-GC electrode obtained in 50 (a), 25 (b), 10 (c) and $5 \mathrm{mmol} \mathrm{L}^{-1}$ glucose (d), respectively. The potential sweep rate is $0.005 \mathrm{mV} \mathrm{s}^{-1}$.

with equations 26 reveals that the rate constant of reaction $8, \mathrm{k}_{2} \Gamma$ and the ratio of $\mathrm{k}_{-1}^{\mathrm{o}} / \mathrm{k}^{\mathrm{o}}{ }_{1}$ are $2.33 \times 10^{-10} \mathrm{~cm} \mathrm{~s}^{-1}$ and $2.81 \times 10^{8}$, respectively. Figure $10 \mathrm{C}$ presents the variation of the intercepts of the lines in Figure 10A with the applied potential in a semi-log scale. Using this graph and equation 26 the magnitudes of $\mathrm{k}_{1}^{\mathrm{o}} \Gamma$ and the anodic transfer coefficient of $4.71 \times 10^{-8} \mathrm{~mol} \mathrm{~s}^{-1} \mathrm{~cm}^{-2}$ and 0.43 have been obtained. From the above findings the value of $\mathrm{k}_{-1}^{\mathrm{o}} \Gamma$ was worked out to be $1.32 \times 10 \mathrm{~mol} \mathrm{~s}^{-1} \mathrm{~cm}^{-2}$. Similar pseudo-steady state polarization curves were collected for fructose, arabinose, lactose, maltose and sucrose. The values of $\mathrm{k}_{2} \Gamma, \mathrm{k}_{1}^{\mathrm{o}} \Gamma$ and $\alpha$ obtained according to the method described above for these carbohydrates were reported in Table 3 .

Table 3. Values of the $\mathrm{k}_{2} \Gamma, \mathrm{k}_{1}^{\mathrm{o}} \Gamma$ and $\alpha$ obtained from polarization curves

\begin{tabular}{lccc}
\hline$\alpha$ & $\mathrm{k}_{1}^{\mathrm{o}} \Gamma /\left(\mathrm{mol} \mathrm{s}^{-1} \mathrm{~cm}^{-2}\right)$ & $\mathrm{k}_{2} \Gamma /\left(\mathrm{cm} \mathrm{s}^{-1}\right)$ & carbohydrates \\
\hline $0.43 \pm 0.03$ & $4.71 \times 10^{-8}$ & $2.33 \times 10^{-10}$ & Glucose \\
$0.48 \pm 0.02$ & $9.11 \times 10^{-8}$ & $1.04 \times 10^{-9}$ & Fructose \\
$0.44 \pm 0.02$ & $2.53 \times 10^{-9}$ & $8.30 \times 10^{-11}$ & Arabinose \\
$0.59 \pm 0.02$ & $3.33 \times 10^{-8}$ & $5.88 \times 10^{-9}$ & Lactose \\
$0.41 \pm 0.04$ & $7.05 \times 10^{-9}$ & $6.64 \times 10^{-11}$ & Sucrose \\
$0.51 \pm 0.03$ & $1.12 \times 10^{-8}$ & $5.31 \times 10^{-10}$ & Maltose \\
\hline
\end{tabular}

For undergoing electrochemical oxidation these molecules have to get adsorbed on the electrode surface, which can occur by formation of $\mathrm{H}$-bonds between the $\mathrm{OH}$ groups and the cobalt hydroxide layer. The electron transfer is likely to be more efficient when an $\mathrm{OH}$ group attached to a carbon atom adjacent to the $\mathrm{C}=\mathrm{O}$ group becomes involved in adsorption. It can be seen that lactose has several $\mathrm{OH}$ groups (scheme 1) fructose has two $\mathrm{OH}$ groups $\left(\mathrm{C}_{1}\right.$ and $\mathrm{C}_{3}$
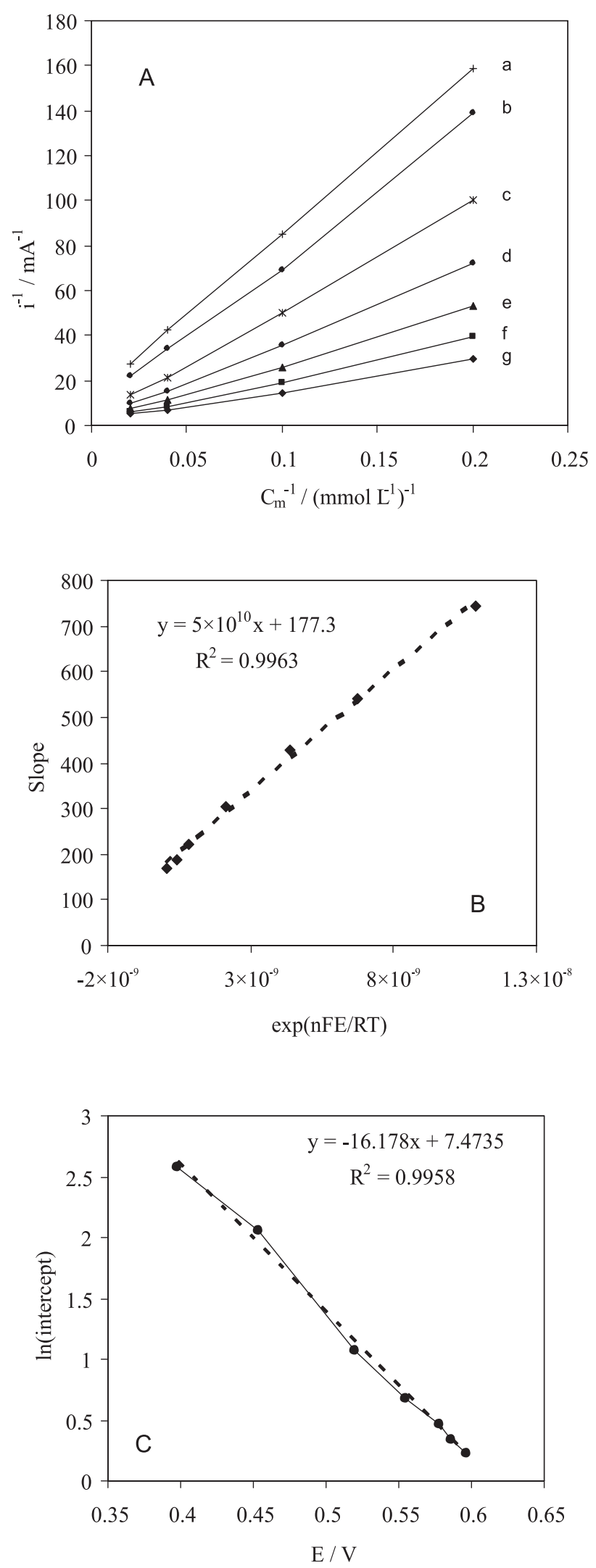

Figure 10. A: Plot of $i^{-1}$ (from polarization curves in Figure 9) against $C_{m}^{-1}$ at various potentials: $470,483,509,534,561,585,612 \mathrm{mV} / \mathrm{SCE}$ as curves (a-g). B: Plot of the slopes (of curves in A) vs. exp (-nFE/RT). C: Plot of the ln (intercepts) (of curves in A) vs. applied potential. 
in Scheme 1), thus making the former oxidation statistically more probable. This may be the reason behind the enhanced electrochemical oxidation kinetics of lactose compared to fructose and other carbohydrates. It is clear that the presence of a larger number of hydroxyl groups facilitates the oxidation. It appears that the presence of at least two hydroxy groups constitutes a minimum requirement for facile oxidation.

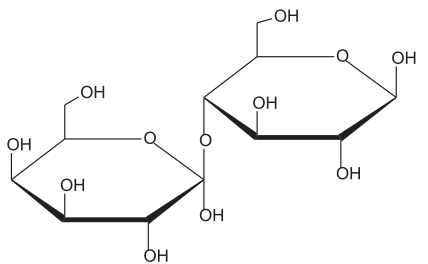

(1)

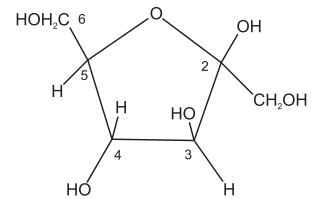

(2)
Scheme 1. Chemical structure of lactose (1) and fructose (2).

\section{Conclusions}

This work presents the preparation and usefulness of cobalt hydroxide (oxide) modified glassy carbon electrodes for electro-oxidation of carbohydrates in alkaline solution. The electrode was electrocatalytically active around $530 \mathrm{mV} / \mathrm{SCE}$ where the carbohydrate on GC electrode showed no activity. Chronoamperometric experiments showed a large anodic current at the oxidation potential of low valence cobalt hydroxide (oxide) in further support of the mediated electro-oxidation. Using cyclic voltammetry and chronoamperometry techniques, the kinetic parameters of these carbohydrates, such as charge-transfer coefficient, catalytic reaction rate constant and diffusion coefficient for oxidation, were determined. Oxidation of monosaccharide and disaccharide on these modified electrodes is found to follow a catalytic EC' mechanism in which $\mathrm{Co}(\mathrm{IV})$ is continuously generated and consummed on the surface. Within these carbohydrates lactose is oxidized more easily than sucrose owing to the presence of greater number of hydroxy groups adjacent to the carbonyl group in the former case. The unique properties of this electrode suggest several potential analytical applications. First, the electrode may be used as a detector in liquid chromatography or capillary electrophoresis. The electrode may also be used as a glucose sensor in some environments. Finally we noticed that the peak current values exhibited a linear dependence on concentration of glucose, suggesting the utility of the modified electrodes for analytical applications. This analytical aspect is under study and will be presented in detail in our future communications.

\section{Reference}

1. Wasmus, S.; Kuver, A.; J. Electroanal. Chem. 1999, 461, 14.

2. Liu, H.; Song, C.; Zhang, L.; Zhang, J.; Wang, H.; Wilkinson, D. P.; J. Power Sources 2006, 155, 95.

3. Lamy, C.; Rousseau, S.; Belgsir, E. M.; Coutanceau, C.; Leger, J. M.; Electrochim. Acta 2004, 49, 3901.

4. Zadeii, J. M.; Marioli, J.; Anal. Chem. 1991, 63, 649.

5. Santos, L. M.; Baldwin, R. P.; Anal. Chem. 1987, 59, 1766.

6. Reim, R. E.; Van Effen, R. M.; Anal. Chem. 1986, 58, 3203.

7. Zhang, X.; Chan, K.Y.; Tseung, A. C. C.; J. Electroanal. Chem. 1995, 386, 241.

8. Wang, J.; Taha, Z.; Anal. Chem. 1990, 62, 1413.

9. Deo, R. P.; Wang, J.; Electrochem. Commun. 2004, 6, 284.

10. Lee, J.; Park, S. M., Anal. Chim. Acta 2005, 545, 27.

11. Ojani, R.; Raoof, J. B.; Salmany-Afagh, P.; J. Electroanal. Chem. 2004, 571, 1.

12. Park, S.; Chung, T. D.; Kim, H. C.; Anal. Chem. 2003, 75, 3046.

13. Tominaga, M.; Shimazoe, T.; Nagashima, M.; Kusuda, H.; Kubo, A.; Kuwahara, Y.; Taniguchi, I.; J. Electroanal. Chem. 2006, 590, 37.

14. Bamba, K.; Leger, J. M.; Garnier, E.; Bachmann, C.; Servat, K.; Kokoh, K. B.; Electrochim. Acta 2005, 50, 3341.

15. Parpot, P.; Pires, S. G.; Bettencourt, A. P.; J. Electroanal. Chem. 2004, 566, 401.

16. Torto, N.; Ruzgas, T.; Gorton, L.; J. Electroanal. Chem. 1999 , 464, 252.

17. Parpot, P.; Kokoh, K. B.; Belgsir, E. M.; Leger, J. M.; Beden, B.; Lamy, C.; J. Appl. Electrochem. 1997, 27, 25.

18. Governo, A. T.; Proenca, L.; Parpot, P.; Lopes, M. I. S.; Fonseca, I. T. E.; Electrochim. Acta 2004, 49, 1535.

19. Danaee, I.; Jafarian, M.; Forouzandeh, F.; Gobal, F.; Mahjani, M. G.; Electrochim. Acta 2008, 53, 6602.

20. Cataldi, T. R. I.; Guerrieri, A.; Casella, I.; Desimoni, E.; Electroanalysis 1995, 7, 305

21. Prabhu, S. V.; Baldwin, R. P.; Anal. Chem. 1989, 61, 852.

22. Prabhu, S. V.; Baldwin, R. P.; Anal. Chem. 1989, 61, 2258.

23. Luo, P.; Prabhu, S. V.; Baldwin, R. P.; Anal. Chem. 1991, 62, 752.

24. Prabhu, S. V.; Baldwin, R. P.; J. Chromatogr. 1991, 513, 227.

25. Luo, P.; Zhang, F.; Baldwin, R. P.; Anal. Chim. Acta 1991, 244, 169.

26. Luo, M. Z.; Luo, P.; Baldwin, R. P.; J. Chem. Educ. 1993, 711, 679.

27. Zadeii, J. M.; Marioli, J.; Kuwana, T.; Anal. Chem. 1991, 63, 649.

28. Xie, Y.; Huber, C. O.; Anal. Chem. 1991, 63, 1714.

29. Mannino, S.; Rossi, M.; Ratti, S.; Electroanalysis 1991, 3, 71 I.

30. Colon, L. A.; Dadoo, R.; Zare, R. N.; Anal. Chem. 1993, 65, 476. 
31. Ye, J.; Baldwin, R. P.; Anal. Chem, 1993, 65, 3525.

32. Majumdar, G.; Goswami, M.; Sarma, T. K.; Paul, A.; Chattopadhay, A.; Langmuir 2005, 21, 1663.

33. Palmore, G. T. R.; Kim, H. H.; J. Electroanal. Chem. 1999, 464,110

34. Heller, A.; Phys. Chem. Chem. Phys. 2004, 6, 209.

35. Casella, I.G.; J. Electroanal. Chem. 2002, 520, 119.

36. Jafarian, M.; .Mahjani, M. G.; Heli, H.; Gobal, F.; Khajehsharifi, H.; Hamedi, M. H.; Electrochim. Acta 2003, 48, 3423.
37. Barbero, C.; Planes, G. A.; Miras, M. C.; Electrochem. Commun. 2001, 3, 113.

38. Bruckenstein, S.; Shay, M.; J. Electroanal. Chem. 1985, 188, 131.

39. Laviron, E.; J. Electroanal. Chem. 1979, 101, 19.

40. Bard, A. J.; Faulkner, L. R.; Electrochemical Methods, John Wiley and Sons: New York, 2001.

41. Harrison, J. A.; Khan, Z. A.; J. Electroanal. Chem. 1970, 28 , 131. 